\title{
Teacher Competencies and Instructional Strategies Utilization for Skill Acquisition of Business Education Students in Nigeria
}

\author{
T. A. Umoru ${ }^{1} \&$ Yusuf Shaibu ${ }^{2}$ \\ ${ }^{1}$ Department of Business and Entrepreneurship Education, College of Education, Kwara State University, Malete, \\ Nigeria \\ ${ }^{2}$ Department of Office Technology and Management, School of Communication and Information Technology \\ Federal Polytechnic, Offa., Kwara State, Nigeria \\ Correspondence: T. A. Umoru, Department of Business and Entrepreneurship Education, College of Education, \\ Kwara State University, Malete, Nigeria.
}

Received: March 1, 2018

Accepted: June 10, 2018

Online Published: June 29, 2018

doi:10.20849/aes.v3i3.408

URL: https://doi.org/10.20849/aes.v3i3.408

\begin{abstract}
The study examined the extent of the influence of teacher competencies and instructional strategies utilization for skill acquisition of office technology and management students in polytechnics in South-Western Nigeria. The study adopted descriptive survey design. Two research questions guided the study and two null hypotheses were tested at 0.05 level of significance. The population of the study consisted of 152 lecturers and instructors in all the accredited polytechnics in South-Western Nigeria. There was no sampling since the population was manageable. The data for the study was collected through questionnaire which was duly validated by three experts. With the use of Cronbach Alpha Reliability Test (CART), the reliability co-efficient calculated for the study was found to be 0.868 which indicated that the instrument for the study was reliable. Mean and standard deviation were the tools used to analyze the research questions while the hypotheses were tested using independent t-test statistics at 0.05 level of significance. The study found that teaching competencies has positive influence on skill acquisition among OTM students in polytechnics to a great extent. Based on these findings, it was concluded that lecturers are competent in teaching relevant skills to the students in polytechnics. It was therefore, recommended, among others, that the Lecturers should be trained and retrained in order to keep them abreast and competent with the current trends in curriculum and instruction of OTM courses and for effective service delivery.
\end{abstract}

Keywords: competencies, instructional, strategies, skill acquisition

\section{Introduction}

There is no doubt that the future of business education as a discipline depends on the readiness of business Education teachers to impart the knowledge and skills of technology to Office Technology and Management students. The need for business education teachers to acquire modern office technology skills can, therefore, not be overstressed as this is indispensable if teachers are to impart these skills to the students so that they would be adequately prepared for the demands of the current technological innovations in business offices. Business Educators are also supposed to be able to apply ICT in teaching and learning of office technology skill courses if they are to adequately deliver instructions to students (Omeje, 2009).

In Nigerian polytechnics, there are two categories of teachers; Lecturers and Instructors. Lecturers are teachers with university background. These are supposed to handle mainly theoretical aspects of pedagogy; while Instructors are teachers with polytechnic and technical background. This category of teachers handle mainly the practical/technical aspects of teaching. While Instructors pride themselves in the knowledge of practical secretarial skills, the Lecturers often deride their lack of theoretical depth; hence the relationship between the Lecturers and Instructors is often conflict-prone.

There is always a degree of gender imbalance among teachers of OTM in Nigerian polytechnics since Secretarial profession was for long regarded as occupation of the feminine gender. Female teachers consequently dominate secretarial practice and pedagogy. However, the introduction of ICT into secretarial practice has brought the 
profession and its pedagogy within the male comfort zone. In OTM as in many other professions, there is often gender disparity in perceptions of professional approaches and ideals.

For effective delivery of business education curriculum; Lecturers and Instructors are expected to possess relevant and adequate ICT-competencies needed to equip business education graduates to face and surmount the challenges of technologies in modern business environment (Madu, Obidi, and Genevive, 2015). Some of the competencies needed include.

Computer Competencies: This includes ability to use spreadsheets, excel, desktop publishing, Adobe Page maker, CorelDraw/graphics in office automation processing. Ability to understand symbolic language like COBOL, FORTRAN and BASIC and ability to create websites through webpage design.

Communication Competencies: This includes ability to use appropriate telephone techniques, ability to use effective oral communication and ability to compose clear and concise letters, punctuation, capitalization and numerical forms.

Word Processing Competencies: This include understanding the relationship between computer applications and word processing, ability to use different word processing software packages in creating different types of documents; ability to activate the computer and other word processing equipment, input data from original sources speedily and accurately (keyboarding). It also include: ability to edit, key-in text, spelling checks of texts and so on; ability to merge new mail with old in part or in full by deleting, adding, formatting by copying and pasting texts; ability to format text and display it in acceptable form according to office standards and procedure through tabulations, display, reports, notices, and minutes .Others include ability to proofread documents on the screen before printing; ability to save and retrieve word processing texts when needed and ability to activate the printer and print out copies.

Data Processing Competencies: This include ability to interpret computer printouts; ability to apply basic processing methods including on-line, interacting, real time, batch, centralized and distributed processing; ability to apply principles of recording data, logging in and out and ability to maintain/updating stored databases.

Telecommunication Competencies: This includes ability to send and receive E-mail. Ability to manage mail services (incoming and outgoing mails); ability to fax messages; ability to operate teleconferencing facilities; ability to send and receive messages through computer networks (LAN, WAN, etc.);ability to send and receive correspondence by telex, telephone, mobile phone and private branch exchange and Ability to know modern telecom and their functions.

Planning, Organizing and Decision making competencies: This includes ability to organize workstations for maximum efficiency utilization; ability to supervise work effectively; ability to manage time and task efficiently and ability to accurately interpret material flows, implement procedures and recommend changes in the system.

Reprographic Competencies: This includes ability to save code index and retrieve documents or disks, microfilms and other magnetic media; ability to access files using appropriate techniques such as serial and random access; ability to capture, files creation, files updating, report writing and file inquiry; ability to operate electronic filling, indexing and cataloguing and ability to apply the principle of electronic referencing.

Manipulative skill development requires a blending of the mind and muscle. Manipulative acts are guided by thought and a direct relationship exists between the quality of thought and quality of manipulative performance. Watson (2006) stated that psychomotor skill development involves both muscle and thinking skills. According to Watson, psychomotor skills are acquired through a three stage process:

Early cognitive usually of short duration and includes attention, observation and thought about how and why the skill is performed, lengthy practice or fixation includes practice sessions aimed at shaping correct performance and finally at the automatic stage, correct performance becomes automatic, with increases in speed, accuracy, dexterity, timing and greater understanding of application setting. Unfortunately, polytechnic students do not always reach the final autonomous automatic stage? However, advanced stages of skill acquisition process are often attainable.

Psychomotor skill variables synthesize empirical based conclusions, as well as relevant theory, regarding the processes of psychomotor skill development. The variables to be contained in this discussion include motivation, demonstrations, physical practice, mental practices and feedback/knowledge of results. Actual demonstration has been widely viewed as the most appropriate strategy for teaching skill development. According to Gould and Roberts (2002), filmed demonstrations have also been found to enhance psychomotor skill development because it enhances psychomotor skill acquisition, the higher the status of the person presenting the demonstration, the greater the influence of the demonstration on the student's skill acquisition, tasks should be broken into subunits 
for teaching purpose so that the skills involved in each subunit could be demonstrated in sequence, allowing students to practice in each subunit before moving to the next and demonstrations can help reduce anxiety over performing unfamiliar skills.

Practices may be defined as "...repetition with the intent of improved performance" (Watson, 2006). Actual practice of a manipulative skill is essential to acceptable performance. Furthermore, actual performance of a skill effectively reduces the fear and anxiety that accompanies the performance of many skills (Gould and Roberts, 2002). Distributed practice is more effective in the development of psychomotor skills than massed practice (Fischman, Christina and Vercruyssen, 2003). That is short frequency practice sessions over a long period of time are most effective. However, according to him, practice sessions must be long enough to allow improvement, and the time period between sessions must be short enough to prevent forgetting. Performance curves tend to reveal that improvement is usually fastest initially, with a plateau of performance reached after some time. Research evidence suggests, however, that these plateaus are primarily due to student's stopping at their own acceptable levels of performance, rather than to any physical limitations (Watson, 2006).

Feedback/Knowledge of Results - Feedback, or information provided to students regarding their performance results, is essential in psychomotor skill development (Watson, 2006; Braverman and DeCaro. 2009). In order to provide appropriate and timely feedback, psychomotor skills must be identified as open loop, where no feedback can be received until the task is complete (e.g., website creation), where feedback, error detection and correction are possible during the course of performing the skill These website design skills are usually complex skills that may be broken down into component parts (e.g., linking text and documents). They offered the following conclusions regarding feedback and its effects on skill acquisition:

- The rate of skill improvement depends upon the precision and frequency of knowledge of results.

- A delay in providing this knowledge does not affect skill acquisition. However, feedback is important, especially in the early stages of practicing a simple website design.

- Withdrawal of knowledge of results decreases performance in the early stages of skill development but does not affect performance in the late stages.

- A variety of types of feedback should be provided, including visual, verbal and kinaesthetic. The use of video-taped and verbal feedback increases performance on website design complex skills.

Motivation-A student's motivation has a positive influence on the development of psychomotor skills. If experience were to be educational, they must account for the principle of puzzlement or indeterminacy. That is, the major step in the teaching process is to create an atmosphere of confusion or perplexity in the student's minds about the problem (skill) at hand (Dewey, 1999). From a review of research studies Watson (2006) presented the following strategies for increasing motivation: (a) use a variety of psychological strategies based upon personal goals and interests, values of the skill, and personal challenge (b) arouse curiosity by presenting a novel idea or a puzzling problem (c) set challenging, yet obtainable standards for each student (d) providing feedback and reinforcement and (e) take advantage of natural tendencies to compete.

\section{Statement of the Problem}

The advent of ICT meant that new facilities have to be acquired and curriculum updated, while teachers, also have to be continually retrained. The researcher observed that in some polytechnics, lecturers with computer background who cannot apply the ICT courses to the secretarial office function have been teaching OTM students these courses due to lack of competent OTM Lecturers and Instructors in ICT office applications. The situation demands that programmes input be regularly evaluated to ensure that they do not lag behind in the fast pace of the ICT revolution and contemporary office realities. If this is not done, secretarial teachers may discover that they are training tomorrow's secretaries and office managers for yesterday's office. This will have great implications for the quality of office work and economic productivity. The concern of this study is to focus on the influence of teachers' competencies and instructional strategies utilization for skill acquisition of business education students in Nigeria.

\section{Purpose of the Study}

The main purpose of this study is to examine the influence of teacher competencies and instructional strategies on office technology and management students' skill acquisition as perceived by polytechnics business educators in South-Western Nigeria. Specifically, the study will examine the extent of:

1. Teacher competency on students' skill acquisition in polytechnics in South-Western Nigeria; 
2. Instructional strategies utilization on students' skill acquisition in polytechnics in South-Western Nigeria.

\section{Research Questions}

1. To what extent do teaching competencies influence skill acquisition among OTM students in polytechnics in South-Western Nigeria?

2. To what extent do instructional strategies utilization adopted by OTM teachers influence skill acquisition among OTM students in polytechnics in South-Western Nigeria?

\section{Hypotheses}

The following hypotheses were formulated to guide the study:

1. $\mathrm{Ho}_{1}$ There is no significant difference in the mean ratings of lecturers and instructors on the extent to which teaching competencies influence students' skill acquisition among OTM teachers in polytechnics in South-Western Nigeria.

2. $\mathrm{Ho}_{2}$ There is no significant difference in the mean ratings of male and female respondents on the extent to which Instructional strategies utilization adopted by OTM teachers influence skill acquisition among OTM students in Polytechnics in South-Western Nigeria.

\section{Methods}

For the purpose of this study, descriptive survey design was used. The population for the study consisted of 152 Lecturers and Instructors in the department of Office Technology and Management in the accredited polytechnics offering the course in South-Western Nigeria as follows Federal Polytechnic Ado-Ekiti 12: Yaba College of Technology Lagos State 14: Lagos State Polytechnic Ikorodu13: Grace Polytechnic,. Alhaji Masha,Surulere 10: Lagos City Polytechnic, Ikeja 10: Federal Polytechnic, Ilaro, Ogun State 13: Moshood Abiola Polytechnic, Abeokuta 12: Gateway Polytechnic, Saapade 11: Rufus Giwa Polytechnic,Owo, Ondo State 12: Federal. Polytechnic, Ede. Osun State 14: Osun State Polytechnic, Iree 08: The Polytechnic, Ibadan, Oyo State 12: The Ibarapa Polytechnic, Eruwa 11. The researcher decided to study the entire population in line with the postulate of Ademiluyi and Okwuanaso (2009) That it is ideal to study the entire population when it is manageable.Therefore, there was no sample for the study. One hundred and forty-seven copies of questionnaires were retuned and analysed by the researcher out of one hundred and fifty-two (152) copies that were distributed to lecturers and instructors. The study relied on the perception of the Lecturers and Instructors in these polytechnics. It also covered ICT skill acquisition of OTM students. The Likert four point rating scale was adopted. The responses were weighted on the following bases; Very Great Extent (VGE) 4 points, Great Extent (GE) 3 points, Small Extent (SE) 2 points and Very Small Extent (VSE) 1 point.

The data collected to answer the research questions were analysed using mean scores and standard deviation. Hypotheses were tested using independent t-test statistics at 0.05 level of significance. Items with mean rate of less than or equal to 1.49 were rated as having been influenced to "very small extent". Items with mean values of between 1.5 and 2.49 were rated as having been influenced to a "small extent". Items with mean values of between 2.5 and 3.49 were rated as having been influenced to a "great extent" while items with mean value of 3.50 and above were rated as having been influenced to a "very great extent".

For the hypotheses, the critical or table value was compared with the calculated value from the analyzed data to decide whether the null hypotheses will be accepted or rejected. The rule is to reject the null hypothesis when the calculated value is greater than or equal to the critical value, or to accept the null hypothesis when the calculated value is less than or equal to the critical value (Baba, 2009). 


\section{Results}

7.1 Research Question One: To What Extent Do Teaching Competencies Influence Skill Acquisition Among OTM Students in Polytechnics in South-Western Nigeria?

Table 1. Mean and standard deviation of responses on the extent to which teaching competencies influence skill acquisition among OTM students in polytechnics in South-western Nigeria

\begin{tabular}{|c|c|c|c|c|}
\hline $\mathrm{S} / \mathrm{N}$ & Item Statements & $\overline{\mathrm{X}}$ & SD & Remarks \\
\hline 1. & $\begin{array}{l}\text { Teachers' proficiency in CorelDraw helps students' skill acquisition } \\
\text { in Desktop Publishing }\end{array}$ & 3.41 & 0.87 & Great Extent \\
\hline 2. & $\begin{array}{l}\text { Teachers' proficiency in website design help students' skill } \\
\text { acquisition in Webpage Design }\end{array}$ & 3.24 & 1.00 & Great Extent \\
\hline 3. & $\begin{array}{l}\text { Teachers' keyboarding dexterity helps students' skill acquisition in } \\
\text { Word Processing. }\end{array}$ & 3.31 & 0.90 & Great Extent \\
\hline 4. & $\begin{array}{l}\text { Teachers' shorthand dexterity helps students' skill acquisition in } \\
\text { shorthand. }\end{array}$ & 3.48 & 0.70 & Great Extent \\
\hline 5. & $\begin{array}{l}\text { Teachers' presentation with projector helps students' skill acquisition } \\
\text { in PowerPoint presentation. }\end{array}$ & 3.52 & 0.69 & $\begin{array}{l}\text { Very Great } \\
\text { Extent }\end{array}$ \\
\hline 6. & $\begin{array}{l}\text { Teachers' proficiency in spreadsheet helps students' skill acquisition } \\
\text { in Microsoft Excel application }\end{array}$ & 3.51 & 0.70 & $\begin{array}{l}\text { Very Great } \\
\text { Extent }\end{array}$ \\
\hline 7. & $\begin{array}{l}\text { Teachers' use of instructional software (tutorials, drills and practice) } \\
\text { helps students' skill acquisition in advanced keyboarding. }\end{array}$ & 3.42 & 0.70 & Great Extent \\
\hline 8. & $\begin{array}{l}\text { Teachers' proficiency in database creation helps students' skill } \\
\text { acquisition in Database Management packages. }\end{array}$ & 3.54 & 0.69 & $\begin{array}{l}\text { Very } \\
\text { Extent }\end{array}$ \\
\hline 9. & $\begin{array}{l}\text { Teachers' use of e-mail helps students' skill acquisition in e-mail } \\
\text { application. }\end{array}$ & 3.38 & 0.84 & Great Extent \\
\hline 10. & $\begin{array}{l}\text { Teachers' proficiency in video conferencing helps students' skill } \\
\text { acquisition in video conferencing system. }\end{array}$ & 3.51 & 0.67 & $\begin{array}{l}\text { Very Great } \\
\text { Extent }\end{array}$ \\
\hline \multicolumn{2}{|c|}{ Weighted average } & 3.43 & 0.78 & Great Extent \\
\hline
\end{tabular}

$\mathrm{N}_{\mathrm{L}}=94$ and $\mathrm{N}_{\mathrm{I}}=53 ; \mathrm{N}_{\mathrm{L}}$ Number of Lecturers; $\mathrm{N}_{\mathrm{I}}$ Number of Instructors; Source: Field Survey, 2017

Table 1 revealed that the respondents indicated that teachers' proficiency in CorelDraw helps students' skill acquisition in Desktop Publishing to a great extent (mean $=3.41$ ), the same way teachers' proficiency in website design help students' skill acquisition in Webpage Design to a great extent (mean $=3.24$ ). In addition, the respondents indicated that teachers' keyboarding dexterity helps students' skill acquisition in Word Processing to a great extent (mean $=3.31)$, and teachers' shorthand dexterity helps students' skill acquisition in shorthand to a great extent (mean $=3.48$ ). The respondents indicated that teachers' presentation with projector helps students' skill acquisition in PowerPoint presentation to a very great extent (mean $=3.52$ ). Same way the respondent indicated that teachers' proficiency in spreadsheet helps students' skill acquisition in Microsoft Excel application to a very great extent (mean $=3.51$ ), and teachers' use of instructional software (tutorials, drills and practice) helps students' skill acquisition in advanced keyboarding to a great extent (mean $=3.42$ ). In addition, the respondents indicated that teachers' proficiency in database creation helps students' skill acquisition in Database Management packages to a very great extent (mean $=3.54)$. Also, teachers' use of e-mail helps students' skill acquisition in e-mail application to a great extent (mean $=3.38)$, and teachers' proficiency in video conferencing helps students' skill acquisition in video conferencing system to a very great extent (mean $=3.51$ ). All the 10 items have a standard deviation ranging from 0.67 to 1.00 which is below the fixed value of 1.96 . This means that the responses of the respondents were not wide spread as they were close to the mean.

On the overall, all the constructs in the table above indicated that teaching competencies influence skill acquisition among OTM students. This implied that teaching competencies influence skill acquisition among OTM students in polytechnics in South-Western Nigeria to a great extent. This was supported by (mean $=3.43$, $\mathrm{SD}=0.78)$ 
7.2 Research Question Two: To What Extent do Instructional Strategies Utilization Adopted by OTM Teachers Influence Skill Acquisition Among OTM Students in Polytechnics in South-Western Nigeria?

Table 2. Mean and standard deviation of responses on the extent to which instructional strategies utilization adopted by OTM teachers influence skill acquisition among OTM students in polytechnics in South-western Nigeria

\begin{tabular}{|c|c|c|c|c|}
\hline $\mathrm{S} / \mathrm{N}$ & Item Statements & $\bar{X}$ & SD & Remark \\
\hline 1. & Lecture methodology is good for learning office skills. & 2.84 & 0.87 & Great Extent \\
\hline 2. & Demonstration is necessary to master computer skills. & 3.39 & 0.76 & Great Extent \\
\hline 3. & $\begin{array}{l}\text { Repetition with conscious direction when teaching helps to master } \\
\text { skill subjects. }\end{array}$ & 3.31 & 0.72 & Great Extent \\
\hline 4. & $\begin{array}{l}\text { Practice time when broken into short drill periods helps in mastery } \\
\text { of keyboarding skill. }\end{array}$ & 3.21 & 0.78 & Great Extent \\
\hline 5. & $\begin{array}{l}\text { Practice time when broken into short drill periods helps in mastery } \\
\text { of shorthand skill. }\end{array}$ & 3.48 & 0.76 & Great Extent \\
\hline 6. & $\begin{array}{l}\text { Varying drills before the law of diminishing returns start to operate } \\
\text { on the students helps improving their skill acquisition. }\end{array}$ & 3.20 & 0.77 & Great Extent \\
\hline 7. & $\begin{array}{l}\text { Tutorial lessons and exercises help students to acquire CorelDraw } \\
\text { skill in Desktop publishing. }\end{array}$ & 3.20 & 0.76 & Great Extent \\
\hline 8. & $\begin{array}{l}\text { Tutorial lessons and exercises help students to acquire website } \\
\text { creation skill in webpage design. }\end{array}$ & 3.27 & 0.74 & Great Extent \\
\hline 9. & $\begin{array}{l}\text { Developing emotional stability in students helps in building their } \\
\text { skills. }\end{array}$ & 3.35 & 0.76 & Great Extent \\
\hline 10. & $\begin{array}{l}\text { Setting attainable goals for each student helps sustain his/her } \\
\text { interest in skill subjects. }\end{array}$ & 3.35 & 0.74 & Great Extent \\
\hline 11 & $\begin{array}{l}\text { Automatic methodology of skill building helps students to master } \\
\text { the short forms in shorthand. }\end{array}$ & 3.36 & 0.79 & Great Extent \\
\hline 12 & $\begin{array}{l}\text { Positive rather than negative approach to skill building helps } \\
\text { students to master database management technique. }\end{array}$ & 3.39 & 0.81 & Great Extent \\
\hline 13 & Little formal testing helps to build the skills of students effectively. & 3.27 & 0.85 & Great Extent \\
\hline \multicolumn{2}{|c|}{ Weighted average } & 3.28 & $\mathbf{0 . 7 8}$ & Great Extent \\
\hline
\end{tabular}

$\mathrm{N}_{\mathrm{L}}=94$ and $\mathrm{N}_{\mathrm{I}}=53$; Source: Field Survey, 2017

Table 2 reveals that the respondents indicated that lecture methodology is good for learning office skills to a great extent (mean $=2.84$ ), the same way demonstration is necessary to master computer skills to a great extent (mean $=3.39$ ). In addition, the respondents have indicated that repetition with conscious direction when teaching helps to master skill subjects to a great extent (mean $=3.31$ ), and practice time when broken into short drill periods helps in mastery of keyboarding skill and shorthand skill to a great extent (mean $=3.21$ and 3.48). The respondents also indicated that varying drills before the law of diminishing returns start to operate on the students helps improve their skill acquisition to a great extent (mean $=3.20)$. Same way the respondents indicated that tutorial lessons and exercises can help students to acquire CorelDraw skill in Desktop publishing, website creation skill in webpage design to a great extent (mean $=3.20,3.27)$, and developing emotional stability in students helps in building their skills to a great extent (mean $=3.35$ ). In addition, the respondents indicated that setting attainable goals for each student helps to sustain his/her interest in skill subjects to a great extent (mean = 3.35). Also, automatic methodology of skill building helps students to master the short forms in shorthand to a great extent (mean $=3.36$ ), and positive rather than negative approach to skill building helps students to master database management technique to a great extent (mean $=3.39$ ). The respondents also indicated that little formal testing helps to build the skills of students effectively to a great extent (mean $=3.27$ ). All the 13 items have a standard deviation ranging from 0.72 to 0.87 which are below the fixed value of 1.96 . This means that the responses of the respondents are not wide spread as they were close to the mean. 


\subsection{Hypotheses Testing}

7.3.1 $\mathrm{H}_{01}$ : There is no significant difference in the mean ratings of lecturers and instructors on the extent to which teaching competencies influence students' skill acquisition in polytechnics in South-Western Nigeria.

Table 3. Summary of t-test of the difference between the mean ratings of lecturers and instructors on the extent to which teaching competencies influence students' skill acquisition in polytechnics in South Western Nigeria

\begin{tabular}{lccccccc}
\hline Group & $\mathbf{N}$ & Mean & SD & t-cal & Df & p-value & Decision \\
\hline Lecturers & 94 & 3.70 & 0.36 & & & & \\
Instructors & 53 & 2.90 & 0.61 & & & 0.000 & $\mathrm{~S}$ \\
\hline
\end{tabular}

Source: Field survey, 2017

The data in Table 3 revealed that there are 94 Lecturers and 53 Instructors. The Lecturers and Instructors responses showed that teaching competencies influence students' skill acquisition in polytechnics to a very great extent $(X=3.70 ; \mathrm{SD}=0.36)$ and $(X=2.90 ; \mathrm{SD}=0.61)$. Their responses are close to the mean as the standard deviations are very low. The table revealed that there was significant difference between the mean ratings of lecturers and instructors on the extent teaching competencies influence students' skill acquisition in polytechnics $\left(\mathrm{t}_{302}=9.366, \mathrm{P}<0.05\right)$. Therefore, the null hypothesis that states that there is no significant difference in the mean ratings of Lecturers and Instructors on the extent to which teaching competencies influence students' skill acquisition in polytechnics in South-Western Nigeria was rejected. This implied that Lecturers and Instructors differ in their responses regarding the extent to which teaching competencies influence students' skill acquisition in polytechnics. Their responses showed that lecturers rated the extent teaching competencies influence students' skill acquisition higher than the instructors did (mean difference $=0.80$ ).

7.3.2 $\mathrm{H}_{02}$ : There is no significant difference in the mean ratings of male and female respondents on the extent to which instructional strategies utilization adopted by OTM teachers influence students' skill acquisition in polytechnics in South-Western Nigeria.

Table 4. Summary of t-test of the difference between the mean ratings of male and female respondents on the extent to which Instructional strategies utilization adopted by OTM teachers influence students' skill acquisition in Polytechnics in South-Western Nigeria

\begin{tabular}{lccccccc}
\hline Group & $\mathbf{N}$ & Mean & SD & t-cal & Df & p-value & Decision \\
\hline Male & 87 & 3.40 & 0.59 & & & & \\
Female & 60 & 3.10 & 0.70 & & 145 & 0.006 & $\mathrm{~S}$ \\
\hline
\end{tabular}

Source: Field survey, 2017

The data in Table 4 reveals that there are 87 male respondents and 60 female respondents. The male and female responses showed that instructional strategies utilization adopted by OTM teachers influence students' skill acquisition to a great extent $(X=3.40 ; S D=0.59)$ and $(X=3.10 ; S D=0.70)$. Their responses are close to the mean as the standard deviations are very low. The table reveals that there was significant difference between the mean ratings of male and female respondents on the extent to which instructional strategies utilization adopted by OTM teachers influence students' skill acquisition in polytechnics $\left(\mathrm{t}_{145}=2.800, \mathrm{P}<0.05\right)$. Therefore, the null hypothesis that states that there is no significant difference in the mean ratings of male and female respondents on the extent to which instructional strategies utilization adopted by OTM teachers influence students' skill acquisition in polytechnics in South-western Nigeria was rejected. This implied that male and female respondents differ in their responses on the extent to which instructional strategies utilization adopted by OTM teachers influence students' skill acquisition in polytechnics. Their responses showed that male respondents rated the extent higher than the female respondents did (mean difference $=0.30$ ).

\section{Discussion of Results}

The purpose of this study was to examine the influence of teacher competencies and instructional strategies used by teachers for office Technology and management students' skill acquisition as perceived by polytechnics 
business educators in south-western Nigeria. The study found out that teaching competencies influence skill acquisition among OTM students in polytechnics in South-Western Nigeria to a great extent. This means that teachers' proficiency in the use of new technologies influence OTM students skill acquisition. This finding was supported by earlier findings by Ademola (2014) who stated that limited access to internet facilities, and lack of proficiency in ICT are capable of hindering skills acquisition programme, especially in business education programme in tertiary institutions. The finding was supported by an earlier study by Madu, Obidi, and Genevive, (2015) which stated that for effective delivery of OTM curriculum, OTM Lecturers and Instructors are expected to possess relevant and adequate ICT-competencies needed to equip OTM graduates to face and surmount the challenges of technologies in modern business environment. The study also found out that instructional strategies adopted by OTM teachers influence skill acquisition among OTM students in polytechnics in South-Western Nigeria to a great extent. This finding corroborate an earlier study by Watson (2006) which noted that a well-stocked storehouse of strategies will enable teachers to vary the classroom experience to prevent monotony and boredom and keep the learning situation fresh and stimulating. It will also enable him to individualize the learning method as well as the content, each based on student's needs.

The findings revealed that there was significant difference in the mean ratings of Lecturers and Instructors on the extent teaching competencies influence students' skill acquisition in polytechnics in South-Western Nigeria. This means that Lecturers and Instructors differ in their responses as lecturers rated the extent teaching competencies influence students' skill acquisition higher than the Instructors did. This finding was contradicted by an earlier finding by Madu, Obidi, and Genevive, (2015) which stated that there was no significant difference between Lecturers and Instructors adequate ICT-competencies needed to equip OTM graduates to face and surmount the challenges of technologies in modern business environment. The study also found out that there was significant difference in the mean ratings of male and female respondents on the extent to which instructional strategies adopted by OTM teachers influence students' skill acquisition in Polytechnics in South-Western Nigeria. This finding contradict a study by Onojeta, (2014) which stated that there was no significant difference between the mean response of the respondents on the extent of utilization of new technologies for learning in business education in universities in Edo and Delta States of Nigeria.

\section{Conclusion}

Based on the findings of the study which reveals that teacher competencies and instructional strategies positively influenced office technology and management students' skill acquisition to a great extent, it was therefore concluded that lecturers are competent in teaching relevant skills to the students in polytechnics. The implication of this is that the present curriculum of office technology and management as perceived by business educators meets the required skills in the $21^{\text {st }}$ century world of work. It could also be implied from the findings that the competency level of OTM lecturers is enough to teach the required skills.

\section{Recommendations}

Based on the findings of the study, the following recommendations are made:

1. Lecturers should be trained and retrained in order to keep them abreast and competent with the current trends in curriculum and instruction of OTM courses and for effective service delivery.

2. OTM lecturers should be exposed to conferences, seminars and workshops to enhance their competency level on the use of student-centered strategies as a means of enhancing students' performance in OTM courses.

\section{References}

Ademiluyi, I.F., \& Okwuanaso, S.I. (2009). Influence of national board for technical education accreditation on academic quality indices in polytechnics secretarial studies programme. Business Education Journal, 7(1), $1-13$.

Ademola, T.K. (2014). Paradigm shift in knowledge driven economy towards new technologies: implications to Business Education Curriculum in tertiary institutions. Business Education Journal, 2(1), 209-220.

Baba, E.I. (2009). Assessment of adequacy, functionality and utilization of Office Technology for teaching in tertiary institutions in Kogi State. Business Education Journal, 7(1), 114-123.

Braverman, B., \& deCaro, J. (2009). A review of the literature on psychomotor skill development : implications for the teaching of machine use skills. Journal of Industrial Teacher Education, 16(4), 5-18.

Dewey, J. (1999). Experience and education. London: collier-MacMillan Publishers. 
Fischman, M.G., Christina, R.W., \& Vercruyssen, M.J. (2003). Retention and transfer of motor skills: a review for the practitioner. Quest Journal of Education, 33(2), 181-194. https://doi.org/10.1080/00336297.1981.10483753

Gould, D., \& Roberts, G. (2002). Modeling and motor skill acquisition. Quest Journal of Education, 33(2), 214-230. https://doi.org/10.1080/00336297.1981.10483755

Madu, I.C., Obidi, U.E., \& Genevive, O.C. (2015). Challenges of integrating new technologies for teaching and learning in the Business Education Programme of Colleges of Education in South-East Nigeria. Education Journal, Special Issue: New Dimensions in Vocational Business Education Teaching and Learning 4(6), 9-14.

Omeje, T.S. (2009). An assessment of Information and Communication Technology (ICT) skills required by secretarial studies teachers in tertiary institutions in Kogi State. Business Education Journal, 7(1), 81-94.

Onojetah, S.O. (2014). Business Education curriculum and integration of new technology. Business Education Journal, 2(1), 135-148.

Watson, A. (2006). Learning psychomotor skills in TAFE. Sydney, Australia: Institute of Technical and Adult Teacher Education. ERIC Document Reproduction Service.

\section{Copyrights}

Copyright for this article is retained by the author(s), with first publication rights granted to the journal.

This is an open-access article distributed under the terms and conditions of the Creative Commons Attribution license (http://creativecommons.org/licenses/by/4.0/). 